DOI: $10.14720 /$ aas.2016.107.2.22

Agrovoc descriptors: Vitis vinifera, grapevines, grapevine leaf roll virus, plant diseases, viroses, viruses, photosynthesis

Agris category code: F60, h20

\title{
Fiziološki odziv žlahtne vinske trte Vitis vinifera L. na okužbo z zvijanjem listov vinske trte povezanih virusov (GLRaV-1 in GLRaV-1 + GLRaV-3)
}

\author{
Melita ŠTRUKELJ ${ }^{1}$, Jaka RAZINGER ${ }^{2}$, Barbara GRUBAR ${ }^{3}$, Uroš ŽIBRAT ${ }^{4}$, Irena MAVRIČ PLEŠKO ${ }^{5}$, Dominik \\ VODNIK $^{6}$, Gregor UREK ${ }^{7}$
}

Received July 21, 2016; accepted September 15, 2016.

Delo je prispelo 21. julija 2016, sprejeto 15. septembra 2016.

\section{IZVLEČEK}

Bolezen zvijanja listov vinske trte je ena najpomembnejših in najbolj razširjenih virusnih bolezni vinske trte. Povzročitelji te bolezni so $\mathrm{z}$ zvijanjem listov vinske trte povezani virusi (Grapevine leafroll associated viruses, GLRaVs). S poskusom $\mathrm{v}$ rastlinjaku smo od junija do septembra, v rastni sezoni 2014, spremljali in primerjali fiziološke procese na trtah okuženih $z$ enim (GLRaV-1), oziroma $z$ dvema (GLRaV-1 in GLRaV-3) virusoma iz prej omenjenega kompleksa virusov. V sredini rastne sezone (meseca julija) se je negativni učinek na spremljane fiziološke procese $\mathrm{v}$ listih trte močneje izrazil pri mešani okužbi. Neto-fotosinteza (Pn) listov, okuženih Z GLRaV-1 in GLRaV-3, je bila v primerjavi s Pn listov okuženih le z GLRaV-1 enkrat manjša. Podobno zmanjšanje smo opazili tudi pri prevodnosti listnih rež in transpiraciji ter v parametrih, povezanih $\mathrm{s}$ fotokemično učinkovitostjo fotosintetskega aparata (hitrost transporta elektronov po tilakoidi)

Ključne besede: Vitis vinifera L.; bolezen zvijanja listov vinske trte; GLRaV; fotosinteza

\begin{abstract}
PHYSIOLOGICAL RESPONSE OF GRAPEVINE Vitis vinifera L. TO GRAPEVINE LEAFROLL ASSOCIATED VIRUSES (GLRaV-1 and GLRaV-1 + GLRaV-3)

Grapevine leafroll disease is one of the most severe viral diseases of grapevine caused by Grapevine leafroll-associated viruses (GLRaVs). Physiological processes were monitored on grapevines with single (GLRaV-1) and mixed (GLRaV-1 and GLRaV -3) viral infection under greenhouse conditions from June to September, in vegetation period 2014. In the mid of the season (July) negative effects of the virus infections on physiological processes were more severe in mixed than in single infection. The net-photosynthesis (Pn) of the leaves infected with GLRaV-1 and GLRaV-3 reached only a half of the Pn in GLRaV-1 infected grapevines. Similar reduction was found for stomatal conductance, transpiration and parameters related to photochemical efficiency (electron transport rate).
\end{abstract}

Key words: Vitis vinifera L.; grapevine leafroll disease; GLRaV; photosynthesis

1 dr., Oddelek za varstvo rastlin, Kmetijski inštitut Slovenije, Hacquetova ulica 17, 1000 Ljubljana, Slovenija, melita.strukelj@kis.si

2 dr., Oddelek za varstvo rastlin, Kmetijski inštitut Slovenije, Hacquetova ulica 17, 1000 Ljubljana, Slovenija, jaka.razinger@kis.si

3 univ. dipl. inž. agr., Oddelek za varstvo rastlin, Kmetijski inštitut Slovenije, Hacquetova ulica 17, 1000 Ljubljana, Slovenija, barbara.grubar@kis.si

4 dr., Oddelek za varstvo rastlin, Kmetijski inštitut Slovenije, Hacquetova ulica 17, 1000 Ljubljana, Slovenija, uros.zibrat@kis.si

5 dr., Oddelek za varstvo rastlin, Kmetijski inštitut Slovenije, Hacquetova ulica 17, 1000 Ljubljana, Slovenija, irena.mavricplesko@kis.si

6 prof. dr., Oddelek za agronomijo, Biotehniška fakulteta, Jamnikarjeva 101, 1000 Ljubljana, Slovenija, dominik.vodnik@bf.uni-lj.si

dr., Oddelek za varstvo rastlin, Kmetijski inštitut Slovenije, Hacquetova ulica 17, 1000 Ljubljana, Slovenija, gregor.urek@kis.si 


\section{UVOD}

Bolezen zvijanja listov vinske trte je ena najpomembnejših in najbolj razširjenih virusnih bolezni vinske trte na svetu (Martelli in BoudonPadieu, 2006; Martelli, 2014). Prizadene lahko vse sorte in podlage, vendar bolezenska znamenja niso nujno značilna oziroma prepoznavna pri vseh sortah vinske trte (Pearson in Goheen, 1998). Omenjena bolezen skrajšuje življenjsko dobo trt, zmanjšuje pridelek (v povprečju od 15 do $20 \%$, v nekaterih primerih tudi do $40 \%$ ) in posledično povzroča gospodarsko škodo (Endeshaw in sod., 2014; Martelli, 2014).

Bolezen zvijanja listov vinske trte povzročajo $\mathrm{z}$ zvijanjem listov vinske trte povezani virusi (grapevine leafroll-associated viruses; GLRaV) iz družine Closteroviridae (Martelli, 2014). Do danes je opisanih pet $\mathrm{z}$ zvijanjem listov vinske trte povezanih virusov: GLRaV-1, $-2,-3,-4$ in -7 (Martelli, 2014). Izmed virusov, ki so povezani $\mathrm{z}$ boleznijo zvijanja listov vinske trte, sta $\mathrm{v}$ Evropi najbolj razširjena GLRaV-1 in GLRaV-3 (Martelli in sod., 2002; Sforza in sod., 2003), ki se pogosto pojavljata tudi v mešanih okužbah z drugimi virusi (Prosser in sod., 2007; Jooste in sod., 2015). Največjo škodo pri pridelavi grozdja povzročajo okužbe vinske trte z GLRaV-3 (Cabaleiro in Segura, 2006; Douglas in Krüger 2008), ki je, kar se tiče vpliva na pridelavo, tudi najbolj proučevan.

Bolezen zvijanja listov vinske trte povzročajo $\mathrm{z}$ zvijanjem listov vinske trte povezani virusi (grapevine leafroll-associated viruses; GLRaV) iz družine Closteroviridae (Martelli, 2014). Do danes je opisanih pet $\mathrm{z}$ zvijanjem listov vinske trte povezanih virusov: GLRaV-1, $-2,-3,-4$ in -7 (Martelli, 2014). Izmed virusov, ki so povezani $\mathrm{z}$ boleznijo zvijanja listov vinske trte, sta v Evropi najbolj razširjena GLRaV-1 in GLRaV-3 (Martelli in sod., 2002; Sforza in sod., 2003), ki se pogosto pojavljata tudi $\mathrm{v}$ mešanih okužbah $\mathrm{z}$ drugimi virusi (Prosser in sod., 2007; Jooste in sod., 2015). Največjo škodo pri pridelavi grozdja povzročajo okužbe vinske trte z GLRaV-3 (Cabaleiro in Segura, 2006; Douglas in Krüger 2008), ki je, kar se tiče vpliva na pridelavo, tudi najbolj proučevan.

Bolezen negativno vpliva na vinsko trto, pri kateri izzove morfološke in fiziološke spremembe.
Omenjene spremembe so povezane $\mathrm{z}$ motnjami asimilacije $\mathrm{CO}_{2}$, zmanjšajo se prevodnost listnih rež, transpiracija in število kloroplastov (Almási in sod., 1996). Te motnje se lahko pojavijo še pred pojavom vidnih bolezenskih znamenj. Bolezenska znamenja se kažejo kot predčasno medžilno rumenenje pri belih in rdečenje pri rdečih sortah vinske trte. Pozno poleti in jeseni je značilno tudi zvijanje listov (Korošec-Koruza, 1992; Martelli in Boudon-Padieu, 2006; Martelli, 2014). Jagode na grozdih okuženih trt običajno dozorevajo počasneje in neenakomerno, posledica česar so spremenjene vsebnosti sladkorjev, kislin in fenolnih snovi ter obarvanosti jagod. $\mathrm{S}$ tem je zmanjšana kakovost grozdja, posledično pa vina in sadnih sokov (Cabaleiro in sod., 1999; Sampol in sod., 2003; Bertamini in sod., 2004; Endeshaw in sod., 2014; Martelli, 2014).

Razumevanje vpliva GLRaV na vinsko trto otežuje kompleksnost virusov in zelo raznolik fiziološki odziv rastlin na virusne okužbe (Balachandran in sod., 1997). Na fiziološke parametre in količino pridelka vinske trte vplivajo tako virus kot tudi različek ali izolat virusa (Rowhani in sod., 2015). Cabaleiro in sod. (1999) poročajo, da GLRaV-3 ali GLRaV-1 v mešani okužbi z virusom A vinske trte (Grapevine virus A; GVA) zmanjšujejo kakovost grozdja. Nasprotno so Tomažič in sod. (2005) ugotovili, da je bila kakovost grozdja pri trtah okuženih z GLRaV-1 boljša kot pri trtah brez tega virusa, verjetno tudi zaradi manjšega pridelka in posledično hitrejšega dozorevanja jagod okužene trte (Tomažič in sod., 2005).

Po nam znanih podatkih do zdaj še ni bilo raziskave, ki bi primerjala vpliv mešane okužbe $\mathrm{z}$ GLRaV-1 in GLRaV-3 (v nadaljevanju: mešana okužba) in okužbe le z GLRaV-1 na metabolizem vinske trte. $\mathrm{V}$ predstavljeni raziskavi smo ugotavljali, kakšen vpliv ima okužba z GLRaV-1 v primerjavi $\mathrm{z}$ mešano okužbo na izbrane fiziološke procese in parametre (neto fotosintezo, dejansko in potencialno fotokemično učinkovitost PSII, prevodnost listnih rež, transpiracijo, hitrost transporta elektronov po tilakoidi in vsebnost klorofila) žlahtne vinske trte. 


\section{MATERIALI IN METODE DELA}

\subsection{Zasnova poskusa}

V novembru 2013 smo po predhodnem testiranju s DAS-ELISA testom na GLRaV-1 in GLRaV-3 narezali rozge žlahtne vinske trte ('Blaufränkisch'('Modra Frankinja'), 'Rheinriesling' ('Renski rizling') in 'Pinot Gris' ('Sivi Pinot') okužene z GLRaV-1 ter z GLRaV-1 in GLRaV-3. Rozge, dolge okrog $40 \mathrm{~cm}$, smo ukoreninili in posadili $\mathrm{v}$ petlitrske lonce $\mathrm{z}$ mešanico zemlje za pikiranje potaknjencev in vermikulita $\mathrm{v}$ razmerju 2 : 1. Tako pripravljene rastline smo vzdrževali $\mathrm{v}$ rastlinjaku v naslednjih rastnih razmerah: naravna dnevna fotoperioda, temperatura od 25 do $30^{\circ} \mathrm{C}$ (dnevna) in $15^{\circ} \mathrm{C}$ (nočna), zračna vlaga od 40 do $60 \%$. Trte smo zalivali vsak četrti dan oziroma po potrebi in tudi 24 ur pred vsakimi fiziološkimi meritvami. V času poskusa smo trte tretirali $\mathrm{s}$ sistemičnima pripravkoma $\mathrm{z}$ aktivno snovjo heksitiazoks (akaricid) in tebukonazol (fungicid) ter pognojili $\mathrm{z}$ raztopino gnojila NPK 6-3-6 z mikrohranili in dodatkom morskih alg (Unichem). Zaradi bujne rasti smo nove mladike ustrezno prikrajševali.

Meritve izmenjave plinov $\left(\mathrm{CO}_{2}\right.$ in $\left.\mathrm{H}_{2} \mathrm{O}\right)$, s katerimi smo izmerili neto fotosintezo (Pn), prevodnost listnih rež $\left(\mathrm{g}_{\mathrm{s}}\right)$ ter transpiracijo (E), ter meritve fluorescence (ocena fotokemične učinkovitosti), vsebnosti klorofila (Chl) in hitrost transporta elektronov po tilakoidi (ETR) smo opravljali od začetka junija do sredine septembra na tretjem polno razvitem listu. Meritve so bile opravljene med 9. in 12. uro $\mathrm{v}$ rastlinjaku na Kmetijskem inštitutu Slovenije leta 2014. Po vsakem merjenju (3. junij, 17. julij, 11. in 25. avgust, 8. september), smo odvzeli del lista za preverjanje prisotnosti virusov s PCR. Odvzem vzorca smo opredelili kot sistematično napako (enaka poškodba na merjenih listih pri vseh trtah $\mathrm{v}$ poskusu), ki je imela zanemarljiv vpliv na meritve, saj poteka odziv na ranitveni stres navadno le nekaj ur (León in sod., 2001). Opazovali smo tudi pojavljanje bolezenskih znamenj na preučevanih trtah.

\subsection{Preverjanje prisotnosti GLRaV-1 in GLRaV-3}

Serološka detekcija

Prisotnost GLRaV-1 in GLRaV-3 v rastlinskem materialu pred rezanjem rozg in po njihovi saditvi $\mathrm{v}$ lonce smo preverili s testom DAS-ELISA. Pri tem smo uporabili protitelesa in pufre skladno $\mathrm{z}$ navodili proizvajalca (BIOREBA AG, Švica). Vse vzorce smo testirali $\mathrm{v}$ dveh tehničnih ponovitvah. $\mathrm{Na}$ podlagi rezultatov testa ELISA smo pripravili dve obravnavanji s po osmimi trtami: obravnavanje A - okužene z GLRaV-1 in obravnavanje B okužene $\mathrm{z}$ GLRaV-1 in GLRaV-3 (mešana okužba).

\section{Molekularna identifikacija}

Skupno RNA iz listov obravnavanih trt smo izolirali s kompletom MagMAX ${ }^{\text {TM}}$-96. Total RNA Isolation Kit (Ambion, Thermo Fisher Scientific, ZDA) po priporočilih proizvajalca. Za izolacijo smo uporabili napravo MagMAX Express (Ambion, Thermo Fisher Scientific, ZDA). Za izolacijo smo uporabili 4-5 $\mathrm{mg}$ (dva krogca premera $5 \mathrm{~mm}$ ) rastlinskega tkiva. Komplementarno DNA (cDNA) smo iz $2 \mu 1$ izolirane RNA sintetizirali $\mathrm{z}$ uporabo kompleta High-Capacity cDNA Archive Kit (Applied Biosystems, Thermo Fisher Scientific, ZDA) po priporočilih proizvajalca. Izbrani del virusnega genoma smo pomnožili $\mathrm{v}$ cikličnem termostatu Veriti 96-Well Thermal Cycler (Applied Biosystems). Za pomnoževanje GLRaV-1 smo uporabili začetna oligonukleotida LR1hsp70417F/LR1hsp70-737R (Osman in sod., 2007), za GLRaV-3 pa LR3_18345F/LR3-18488R (Bester in sod., 2014). PCR je potekala $\mathrm{v}$ naslednjih razmerah: denaturacija pri $94{ }^{\circ} \mathrm{C}(5 \mathrm{~min}) ; 35$ ciklov pomnoževanja: denaturacija pri $94{ }^{\circ} \mathrm{C}(30 \mathrm{~s})$, naleganje začetnih oligonukleotidov pri $58{ }^{\circ} \mathrm{C}$ za GLRaV-1 in pri $54{ }^{\circ} \mathrm{C}$ za GLRaV-3 (30 s) in podaljševanje pri $72{ }^{\circ} \mathrm{C}(50 \mathrm{~s})$; ter zaključno podaljševanje pri $72{ }^{\circ} \mathrm{C} \quad(7 \mathrm{~min})$. Prisotnost specifičnih pomnoženih produktov PCR smo preverili na $1 \%$ agaroznem gelu.

\subsection{Meritve fizioloških parametrov in procesov}

Pn, $F_{v}{ }^{\prime} / F_{m}{ }^{\prime}, g_{s}, E$ in ETR smo merili s prenosnim merilnikom fotosinteze LI-6400 (Licor, ZDA). V merilno kiveto smo vstavili izbrani list vinske trte tako, da je bila z listom pokrita celotna površina okenca merilne kivete. Koncentracija $\mathrm{CO}_{2}$ je bila uravnana na $380 \mu \mathrm{mol} \mathrm{CO} \mathrm{mol}^{-1}$, temperatura lista na $25^{\circ} \mathrm{C}$ in svetloba na $1000 \mu \mathrm{mol} \mathrm{m} \mathrm{s}^{-1}$, kar je bilo $\mathrm{V}$ svetlobnem saturacijskem območju fotosinteze. Posamezno meritev smo končali, ko je 
bila dosežena stabilna razlika med koncentracijo $\mathrm{CO}_{2} \mathrm{v}$ zraku, ki je bil v kiveto dovajan, in zrakom, ki je iz kivete izstopal.

Potencialno fotokemično učinkovitost (Fv/Fm) smo merili s fluorometrom Mini PAM (Heinz Walz GmbH, Effeltrich, Germany). Pred meritvami smo na liste za 10 minut namestili ščipalko za prilagoditev listov na temotne razmere. S tem smo zagotovili, da so bili vsi fotosistemi II 'odprti' oziroma, da lahko sprejmejo fotone za biokemijsko delo (Stanje 1). Izračunali smo jo kot $\mathrm{F}_{\mathrm{v}} / \mathrm{F}_{\mathrm{m}}=\left(\mathrm{F}_{\mathrm{m}}-\mathrm{F}_{0}\right) / \mathrm{F}_{\mathrm{m}}$, tako da smo najprej izmerili minimalno fluorescenco $\left(\mathrm{F}_{0}\right) \mathrm{z}$ uporabo merilne svetlobe majhne jakosti $\left(0,15 \mu \mathrm{mol} \mathrm{m}^{-2} \mathrm{~s}^{-1}\right.$ fotosintetsko aktivnega sevanja). Nato smo uporabili satuacijski pulz svetlobe $\left(7000 \mu \mathrm{mol} \mathrm{m}{ }^{-2}\right.$ $\mathrm{s}^{-1}$ fotosintetsko aktivnega sevanja, $0,8 \mathrm{~s}$ ), ki je »zaprl« vse fotosisteme II (Stanje 2), da smo izmerili maksimalno fluorescenco $\left(\mathrm{F}_{\mathrm{m}}\right)$ (Lichtenthalter in sod., 2005).

Koncentracijo klorofila $\mathrm{V}$ listih smo izmerili $\mathrm{z}$ napravo SPAD-502 klorofilmeter (Minolta, Osaka,
Japonska). Na vsakem listu smo opravili tri meritve vsebnosti klorofila in izračunali povprečno vrednost.

\subsection{Statistična analiza}

Za ugotavljanje statistično značilnih sprememb parametrov $\mathrm{v}$ času smo obdelali podatke $\mathrm{s}$ programom R (R Development Core Team, 2008) $\mathrm{s}$ paketom $R c m d r$ (v. 2.2-3) in programom GraphPad Prism 5.00 (GraphPad Software, Inc., La Jolla, CA, USA). Obravnavanji A (GLRaV-1) in B (mešana okužba) smo primerjali $\mathrm{z}$ dvosmerno analizo variance (ANOVA, $p \leq 0,05$ ). Proučevana dejavnika sta bila vrsta okužbe (enojna, mešana) in termin meritve. Statistično značilne razlike med obravnavanji po posameznih terminih meritev smo računali z Bonferonnijevim posttestom. Trte obravnavanja A, ki so bile okužene še z GLRaV-3, niso bile vključene $\mathrm{v}$ analizo (preglednica 1). Vse meritve na slikah in preglednici 2 so predstavljene kot povprečje s standardno napako (povprečje \pm s.n.).

\section{REZULTATI}

\subsection{Prisotnost GLRaV-1 in GLRaV-3 v vzorcih vinske trte}

V nekaterih trtah skupine A, ki so bile glede na rezultate testa DAS-ELISA in prvega RT-PCR okužene samo z GLRaV-1, smo pozneje v sezoni potrdili tudi prisotnost GLRaV-3. Te trte (A3, A5 in A6) so bile popolnoma izključene iz fizioloških analiz (preglednica 1). 
Preglednica 1: Prisotnost GLRaV-1 in GLRaV-3 glede na vzorčenje med junijem in septembrom v rastlinjaku na Kmetijskem inštitutu Slovenije leta 2014

Table 1: The presence of GLRaV-1 and GLRaV-3 according to the sampling between June and September in greenhouse of Agricultural institute of Slovenia in 2014

\begin{tabular}{c|cccc|c}
\hline $\begin{array}{c}\text { Rastlina } \\
\text { / Plant }\end{array}$ & \multicolumn{3}{c}{ Meritev / Measurement } \\
\hline & 1 & 2 & 3 & 4 & 5 \\
\hline A1 & + & + & + & + & + \\
\hline A2 & + & + & + & + & + \\
\hline A3* & + & ++ & + & + & + \\
\hline A4 & + & + & + & + & + \\
\hline A5* & + & + & ++ & ++ & + \\
\hline A6* & + & + & ++ & + & + \\
\hline A7 & + & + & + & + & + \\
\hline A8 & + & + & + & + & + \\
\hline B1-B8 & ++ & ++ & ++ & ++ & ++ \\
\hline
\end{tabular}

A, B - razporeditev trt v obravnavanja glede na rezultate testa ELISA in zaporedna številka trte; Rastlina: A okužene z GLRaV-1; B - okužene z GLRaV-1 in GLRaV-3; Meritev: 1, 2, 3, 4, 5 - zaporedna številka meritve (1 3. 6. 2014, 2 - 14. 7. 2014, 3 - 11. 8. 2014, 4 - 25. 8. 2014, 5 - 8. 9. 2014); + - zaznana prisotnost GLRaV-1 s PCR; ++ - zaznana prisotnost GLRaV-1 in GLRaV-3 s PCR; * - trte, ki niso bile vključene v statistično analizo

A, B - distribution of grapevines in treatments based on the results of the ELISA test and the number of the grapevine; Plant: A - GLRaV-1-infected; B - GLRaV-1 and GLRaV-3-infected; Measurement: 1, 2, 3, 4, 5 measurement dates (1 - 3 June 2014, 2 - 14 July 2014, 3 - 11 August 2014, 4 - 25 August 2014, 5 - 8 September 2014); + - GLRaV-1 confirmed by PCR; ++ - GLRaV-1 and GLRaV-3 confirmed by PCR; * - grapevines which were not included in the statistical analysis

\subsection{Vpliv okužbe $z$ GLRaV-1 in mešane okužbe z GLRaV-1 in GLRaV-3 na vinsko trto}

Dvosmerna analiza variance je pokazala, da je vrsta okužbe (enojna, mešana) značilno vplivala na vse merjene parametre, razen na $F_{\mathrm{v}}{ }^{\prime} / \mathrm{F}_{\mathrm{m}}{ }^{\prime}$ in Chl. Termin merjenja je imel značilen vpliv na vse merjene parametre. Pri $\mathrm{Pn}, \mathrm{F}_{\mathrm{v}}{ }^{\prime} / \mathrm{F}_{\mathrm{m}}{ }^{\prime}$ in ETR je bila značilna interakcija obeh dejavnikov (termin merjenja in vrsta okužbe), kar pomeni, da se je pri teh parametrih vrsta okužbe različno odražala glede na termin merjenja.

Bonferonnijev posttest je pokazal značilno razliko med trtami $\mathrm{z}$ enojno okužbo in tistimi $\mathrm{z}$ mešano okužbo pri Pn, ETR, E in $g_{s} v$ sredini julija. Listi trt, okuženih z GLRaV-1, so imeli dvakrat večjo
Pn $\left(9,19 \pm 1,43 \mu \mathrm{mol} \mathrm{CO}_{2} \mathrm{~m}^{-2} \mathrm{~s}^{-1}\right)$ od listov $\mathrm{z}$ mešano okužbo $\left(4,16 \pm 0,60 \mu \mathrm{mol} \mathrm{CO} \mathrm{CO}^{-2} \mathrm{~s}^{-1}\right)$. Značilno manjši vpliv okužbe $\mathrm{z}$ GLRaV-1 v primerjavi z mešano okužbo se je pokazal tudi pri $\mathrm{g}_{\mathrm{s}}, \mathrm{E}$ in ETR Podrobne povprečne vrednosti parametrov in procesov so navedene $\mathrm{v}$ preglednici 2.

$\mathrm{Na}$ listih trt $\mathrm{V}$ našem poskusu se bolezenska znamenja značilna za bolezen zvijanja listov vinske trte niso razvila. Koncentracija klorofila se med obravnavanjema ni bistveno razlikovala. V sredini julija in začetku avgusta je bila pri mešani okužbi koncentracija klorofila sicer nekoliko manjša kot pri okužbi z GLRaV-1, vendar ne značilno. 
Preglednica 2: Povprečne vrednosti fizioloških parametrov in standardna napaka znotraj obravnavanj A (GLRaV-1) in B (GLRaV-1 + GLRaV-3) med junijem in septembrom $2014 \mathrm{v}$ rastlinjaku na Kmetijskem inštitutu Slovenije

Table 2: Mean values and standard error of physiological parameters within the treatments A (GLRaV-1) and B (GLRaV-1 + GLRaV-3) between June and September 2014 in greenhouse of Agricultural institute of Slovenia

\begin{tabular}{llllll}
\hline & $\mathrm{t}$ & $\mathrm{A}$ & & $\mathrm{B}$ & \\
\hline \multirow{4}{*}{$\mathrm{Pn}$} & 1 & $3,84 \pm 0,97$ & $3,88 \pm 0,62$ \\
& 2 & $9,19 \pm 1,43$ & $4,16 \pm 0,60$
\end{tabular}$*$

A, B - razporeditev trt v obravnavanja glede na rezultate molekularnih analiz (A - okužene z GLRaV-1, B - okužene z GLRaV-1 in GLRaV-3); Pn - neto fotosinteza; $\mathrm{g}_{\mathrm{s}}$ - prevodnost listnih rež; E - transpiracija; $\mathrm{F}_{\mathrm{v}}{ }^{\prime} / \mathrm{F}_{\mathrm{m}}{ }^{\prime}-$ dejanska fotokemična učinkovitost PSII; $\mathrm{F}_{\mathrm{v}} / \mathrm{F}_{\mathrm{m}}$ - potencialna fotokemična učinkovitost PSII; ETR - hitrost transporta elektronov po tilakoidi; Chl - klorofil (SPAD meritev); $\mathrm{t}$ - termin meritev; 1, 2, 3, 4, 5 - zaporedna številka meritve $(1$ - 3. 6. 2014, 2 - 14. 7. 2014, 3 - 11. 8. 2014, 4-25. 8. 2014, 5-8. 9. 2014); * - statistično značilna razlika med obravnanvanjem A in B $(p<0,05)$

A, B - distribution of grapevines in treatments based on the molecular analyses (A - GLRaV-1 infected, B GLRaV-1 and GLRaV-3 infected); Pn - neto photosynthesis; $\mathrm{g}_{\mathrm{s}}$ - stomatal conductance; $\mathrm{E}$ - transpiration; $\mathrm{F}_{\mathrm{v}}{ }^{\prime} / \mathrm{F}_{\mathrm{m}}{ }^{\prime}-$ effective quantum yield of PSII; $\mathrm{F}_{\mathrm{v}} / \mathrm{F}_{\mathrm{m}}$ - maximum quantum efficiency of PSII; ETR - electron transport rate; Chl - 
chlorophyll (SPAD measurement); $\mathrm{t}$ - measurement date; 1, 2, 3, 4, 5 - serial number of the measurements $(1-3$ June 2014, 2 - 14 July 2014, 3 - 11 August 2014, 4 - 25 August 2014, 5 - 8 September 2014); * - statistically significant difference between treatments A and B $(p<0,05)$
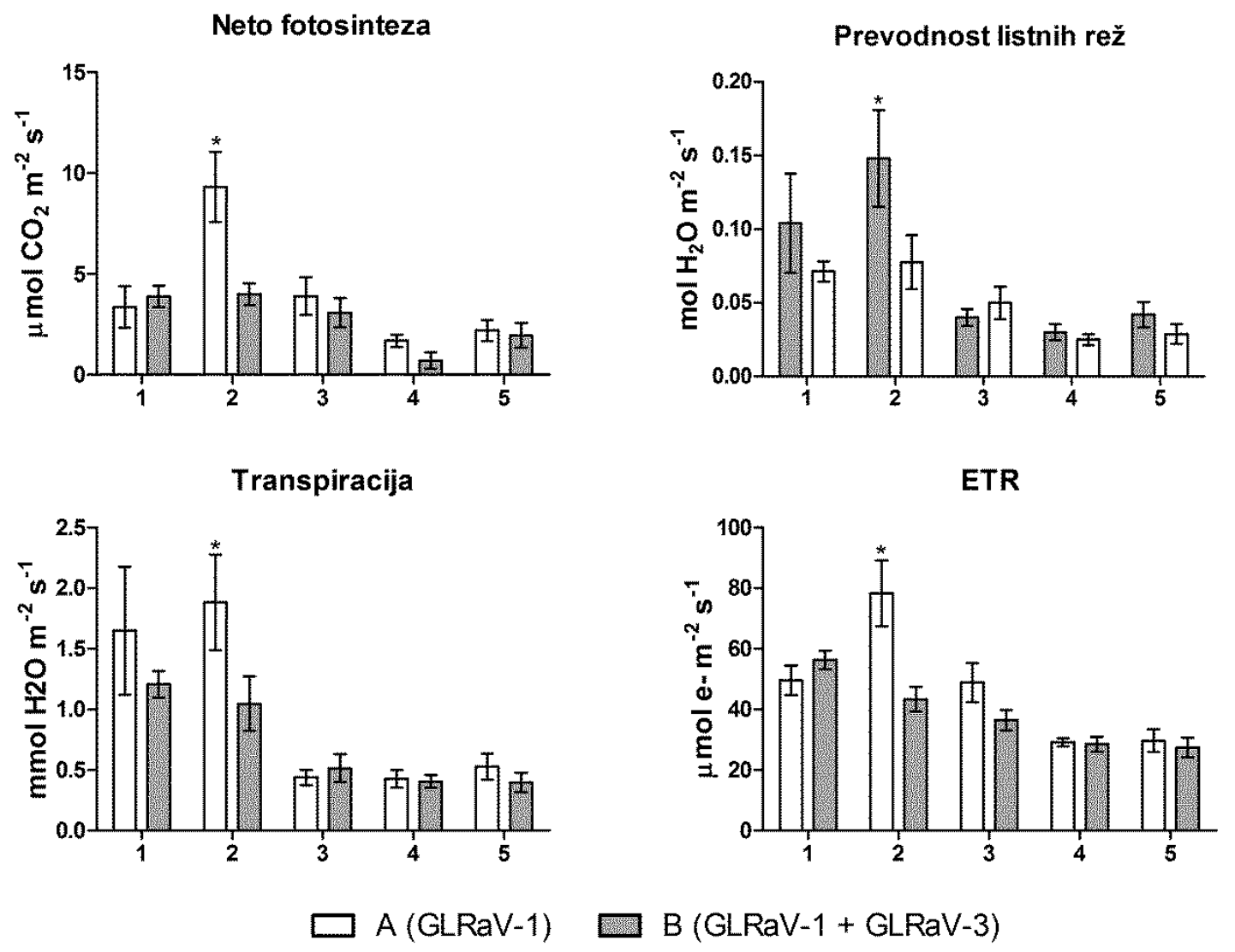

Slika 1: Neto fotosinteza, prevodnost listnih rež, transpiracija in hitrost transporta elektronov po tilakoidi (ETR) pri obravnavanjih A (okužba z GLRaV-1) in B (okužba z GLRaV-1 in GLRaV-3) v petih terminih meritev na žlahtni vinski trti (Vitis vinifera L.) leta 2014. Prikazana so povprečja s standardno napako. 1, 2, 3, 4, 5 - zaporedna številka meritve (1 - 3. 6. 2014, 2 - 14. 7. 2014, 3 - 11. 8. 2014, 4 - 25. 8. 2014, 5 - 8. 9. 2014); * - statistično značilna razlika med obravnavanjema A in B $(p<0,05)$

Figure 1: Net photosynthesis, stomatal conductance, transpiration and thylakoid electron transport rate (ETR) in treatment A (infection with GLRaV-1) and B (infection with GLRaV-1 and GLRaV-3) measured on grapevine (Vitis vinifera $\mathrm{L}$.) in 2014. Average values with standard error are presented. The measurements were performed five times $(1$ - 3. 6. 2014, 2 - 14. 7. 2014, 3 - 11. 8. 2014, 4 - 25. 8. 2014, 5 - 8. 9. 2014); * -significant difference between treatments $\mathrm{A}$ and $\mathrm{B}$ at $p<0.05$

\section{DISKUSIJA}

Po nam znanih podatkih predstavlja študija prvo primerjavo učinka okužbe z GLRaV-1 in mešane okužbe (GLRaV-1 in GLRaV-3) na žlahtno vinsko trto. V primerjavi z okužbo le z GLRaV-1 smo pri mešani okužbi pri drugem merjenju, $\mathrm{v}$ sredini julija, izmerili manjšo neto fotosintezo, počasnejši transport elektronov po tilakoidi, manjšo transpiracijo in prevodnost listnih rež. Sampol in sod. (2003) prav tako poročajo o manjši neto fotosintezi (tudi do $45 \%$, odvisno od starosti lista), prevodnosti listnih rež ter vsebnosti karotenoidov in fluorescenci klorofila kot posledici okužbe vinske trte $\mathrm{z}$ GLRaV ter virusom pahljačavosti listov vinske trte (Grapevine fanleaf virus; GFLV) $\mathrm{v}$ lončnih poskusih. Podobne rezultate merjenj aktivnosti fizioloških procesov $\quad \mathrm{v} \quad \mathrm{z}$ GLRaV 
okuženimi rastlinami so ugotovili tudi pri drugih sortah (Bertamini in sod., 2004; Moutinho-Pereira in sod., 2012).

Tudi drugi virusi, predstavniki drugih rodov in družin, negativno vplivajo na fiziološke parametre v vinski trti. Reynard in Gugerli (2015) sta ugotovila, da $\mathrm{z}$ rdečo packavostjo listov vinske trte povezani virus (Grapevine red blotch-associated virus; GRBaV), ki povzroča podobna bolezenska znamenja kot GLRaV, negativno vpliva na neto fotosintezo, transpiracijo in prevodnost listnih rež. Tako kot $v$ našem poskusu z GLRaV, je bil tudi pri GRBaV vpliv viden že sredi julija, še pred pojavom bolezenskih znamenj. Neto fotosinteza, transpiracija in prevodnost listnih rež so bili za okoli $30 \%$ manjši $\mathrm{v}$ primerjavi $\mathrm{s}$ kontrolno skupino. Gambino in sod., (2012) so ob koncu rastne dobe izmerili manjšo vsebnost klorofila in zmanjšano neto fotosintezo na sorti 'Bosco' okuženi z razbrazdanjem debla skalne in vinske trte povezanim virusom (Grapevine Rupestris stem pitting-associated virus; GRSPaV). Podobno so Basso in sod. (2010) zabeležili značilno zmanjšanje vsebnosti klorofila in fotosintetskega potenciala pri trtah z bolezenskimi znamenji sort 'Cabernet franc' in 'Cabernet sauvignon', ki so bile prav tako okužene z GRSPaV.

Agrotehnični in ampelotehnični ukrepi in razmere okolja vinske trte vplivajo na pojavnost bolezenskih znamenj. O vplivu razmer gojenja na pojavnost znamenj bolezni zvijanja listov vinske trte so poročali Barba in sod. (1989), Cabaleiro in sod. (1997, 1999) ter Christov in sod. (2007). Pri gojenju rastlin okuženih $\mathrm{z}$ GLRaV $\mathrm{v}$ in vitro razmerah Barba in sod. (1989) niso opazili bolezenskih znamenj na listih, čeprav je bila koncentracija virusa po čiščenju pri trtah gojenih $\mathrm{v}$ in vitro razmerah celo 30 -krat večja kot pri trtah $\mathrm{v}$ vinogradu, ki so imele bolezenska znamenja. Tudi Christov in sod. (2007) niso opazili bolezenskih znamenj na listih in vitro gojenih rastlin vzgojenih iz zimskih brstov trt, ki so na polju kazale znamenja okužbe. Podobno tudi v našem poskusu na listih trt $\mathrm{v}$ rastlinjaku nismo opazili bolezenskih znamenj značilnih za bolezen zvijanja listov vinske trte.

Pri razlagi rezultatov moramo torej upoštevati tudi rastne razmere, saj se vrednotenja $\mathrm{v}$ razmerah in vitro, $\mathrm{v}$ lončnih poskusih ( $\mathrm{v}$ rastlinjaku) in na prostem lahko razlikujejo. Cabaleiro in sod. (1997, 1999) v lončnih poskusih niso izmerili značilnih sprememb neto fotosinteze, medtem ko so razlike ugotovili pri poskusu $\mathrm{v}$ vinogradu. Neto fotosinteza pri trtah okuženih z GLRaV-3 je bila za od 53 do $65 \%$ manjša kot pri neokuženih trtah.

Okužba $\mathrm{z}$ enim ali obema virusoma $\mathrm{v}$ našem poskusu ni značilno vplivala na maksimalno potencialno učinkovitost PSII $\left(\mathrm{F}_{\mathrm{v}} / \mathrm{F}_{\mathrm{m}}\right)$, ki je pri vitalnih rastlinah $\mathrm{v}$ dobrem fiziološkem stanju približno $0,83 . F_{v} / F_{m}$ se zmanjša, kadar je rastlina izpostavljena močnemu ali dolgotrajnemu stresu, ki povzroči nepovratne posledice fotosinteznega aparata (Vodnik, 2001). Na zmanjšanje razmerja $\mathrm{F}_{\mathrm{v}} / \mathrm{F}_{\mathrm{m}}$ lahko vplivajo tudi drugi dejavniki, npr. povišanje okoljske temperature. Konstantnost razmerja $\mathrm{F}_{\mathrm{v}} / \mathrm{F}_{\mathrm{m}}$ med merjenji (preglednica 2) nakazuje, da so bile razmere v rastlinjaku primerne za izvajanje poskusa $\mathrm{z}$ vinsko trto in da okužba $\mathrm{z}$ GLRaV ni povzročila nepovratnih poškodb fotosinteznega aparata. $\mathrm{V}$ našem primeru to pomeni, da na podlagi meritev $\mathrm{F}_{\mathrm{v}} / \mathrm{F}_{\mathrm{m}}$ ne moremo ločiti vpliva okužbe $\mathrm{z}$ enim ali obema virusoma pri vinski trti v rastlinjaku. Pri dejanski učinkovitosti PSII $\left(F_{v}{ }^{\prime} / F_{m}{ }^{\prime}\right)$ je opaziti majhne, neznačilne razlike med trtami okuženimi z GLRaV-1 ali z GLRaV-1 in GLRaV-3 (preglednica 2).

Največ raziskav vpliva GLRaV na vinsko trto je bilo narejenih pri trtah okuženih z GLRaV-3, mnogo manj pri trtah okuženih z GLRaV-1 in le nekaj pri trtah z mešanimi okužbami. Raziskovalci so se osredotočali predvsem na kakovost in količino pridelka ter vsebnost snovi $\mathrm{v}$ jagodah (Martelli, 2014). Spring in sod. (2012) v svoji raziskavi niso ugotovili razlik pri vplivu na pridelek med trtami okuženimi $\mathrm{z}$ GLRaV-1 in GFkV ter tistimi okuženimi samo z GLRaV-1. Pri primerjavi vpliva na pridelek med okuženimi in zdravimi trtami so Tomažič in sod. (2003) ugotovili, da okužba trte z GLRaV-1 zmanjša pridelek. Podobno so slabšo rodnost trt opazili Endeshaw in sod. (2014) ob okužbi z GLRaV-3 in Moutinho-Pereira in sod. (2012) ob mešani okužbi z GLRaV-1 in GLRaV-3. Santini in sod. (2011) so ugotovili zmanjšanje pridelka pri mešani okužbi z GLRaV-1 in GVA ne pa tudi pri mešani okužbi z GLRaV-3 in GVA.

Raziskovalci so neodvisno od bolezenskih znamenj in njihovih povzročiteljev dokazali, da je odziv trt na fiziološke procese in pridelek med sortami 
različen (Zufferey in sod., 2000). Zato je pomembno, da študije opravljamo na domačih sortah trt $\mathrm{v}$ lokalnih razmerah. Le na tak način lahko dobimo realne podatke o delovanju procesov $\mathrm{v}$ trti.

\section{ZAKLJUČEK}

V okviru raziskave smo merili fiziološke parametre povezane $\mathrm{s}$ fotosintezo na trtah okuženih samo $\mathrm{z}$ GLRaV-1 ali okuženih z GLRaV-1 in GLRaV-3 v rastlinjaku. Ugotovili smo, da se v začetku junija vrednosti merjenih parametrov med različnimi obravnavanji niso značilno razlikovale. Značilne razlike med okužbo $\mathrm{z}$ enim virusom ter mešano okužbo so se pojavile le pri neto fotosintezi, potencialni fotokemični učinkovitosti PSII, prevodnosti listnih rež, transpiraciji, hitrosti transporta elektronov po tilakoidi in vsebnosti klorofila pri merjenju sredi julija. Na podlagi rezultatov merjenj $\mathrm{v}$ rastlinjaku težko posplošimo, kakšen je vpliv GLRaV na vinsko trto, še posebno pred pojavom bolezenskih znamenj, ali kakšen je njihov vpliv na trte na prostem.

\section{ZAHVALA}

Raziskava je bila financirana s strani ARRS kot del projekta za usposabljanje mlade raziskovalke po pogodbi št. 1000-11-310235 in s finančno pomočjo projekta CropSustaIn (pogodba FP7-REGPOTCT2012-316205).

\section{VIRI}

Almási, A., Eke’, M., Gaborja'ınyi, R. (1996). Comparison of ultrastructural changes ofNicotiana benthamiana infected with three different viruses. Acta Phytopathologica et Entomologica Hungarica, 31, 181-190.

Balachandran, S., Hurry V. M., Kelley, S. E., Osmond, C. B., Robinson, S. A., Rohozinski, J., Seaton, G. G., et al. (1997). Concepts of plant biotic stress, some insightsinto stress physiology of virusinfected plants, from the perspective of photosynthesis. Physiologia Plantarum, 100, 203-213. DOI: $10.1111 /$ j.1399-3054.1997.tb04776.x

Barba, M., Cupidi, A., Faggioli, F. (1989). In vitro culture of grapevine infected by closterovirus type III. Journal of Phytopathology, 126, 225-230. DOI: 10.1111/j.1439-0434.1989.tb01108.x

Basso, M. F., Fajardo, T. V. M., Santos, H. P., Guerra, C. C., Ayub, R. A., Nickel, O. (2010). Fisiologia foliar e qualidade enológica da uva em videiras infectadas por vírus. Tropical Plant Pathology, 35(6) 351-359. http://www.scielo.br/pdf/tpp/v35n6/a03v35n6.pdf

Bertamini, M., Muthuchelian, K., Nedunchezhian, N. (2004). Effect of grapevine leafroll on the photosynthesis of field grown grapevine plants (Vitis vinifera L. cv. Lagrein). Journal of
Phytopathology, 152, 145-152.

DOI: 10.1111/j.1439-0434.2004.00815.x

Bester, R., Pepler, P. T., Burger, J. T., Maree, H. J. (2014). Relative quantitation goes viral: An RTqPCR assay for a grapevine virus. Journal of Virological Methods, 210, 67-75. DOI: 10.1016/j.jviromet.2014.09.022

Cabaleiro, C., Pineiro, A., Segura, A. (1997). Photosynthesis in grapevines infected with leafroll virus (GLRaV-3). V: de Sequera J. S. \& Santos M. T. (Eds.), 12th Meeting of the international council for the study of viruses and virus-like diseases of the grapevine (ICVG). Extended abstracts (153154). Lisbon, Portugal: Oficina Gráfica da Secretaria Geral do Ministerio da Agricultura, do Desenvolvimento Rural e das pescas.

Cabaleiro, C., Segura, A. (2006). Temporal analysis of grapevine leafroll associated virus 3 epidemics. European Journal of Plant Pathology, 114, 441446. DOI: $10.1007 / \mathrm{s} 10658-006-0006-4$

Cabaleiro, C., Segura, A., Garcia-Berrios, J. J. (1999). Effects of Grapevine Leafroll-Associated Virus 3 on the Physiology and Must of Vitis Vinifera L. cv. Albarino Following Contamination in the Field. American Society for Enology and Viticulture, 50, 40-44.

Acta agriculturae Slovenica, 107 - 2, september 2016 
Christov, I., Stefanov, D., Velinov, T., Goltsev, V., Georgieva, K., Abracheva, P., Genova, Y., et al. (2007). The symptomless leaf infection with grapevine leafroll associated virus 3 in grown in vitro plants as a simple model system for investigation of viral effects on photosynthesis. Journal of Plant Physiology, 164(9), 1124-1133. DOI: 10.1016/j.jplph.2005.11.016

Douglas, N., Krüger, K. (2008). Transmission efficiency of grapevine leafroll-associated virus 3 (GLRaV-3) by the mealybugs Planococcus ficus and Pseudococcus longispinus (Hemiptera: Pseudococcidae). European Journal of Plant Pathology, 122, 207-212. DOI: 10.1007/s10658008-9269-2

Endeshaw, S. T., Sabbatini, P., Romanazzi, G., Schilder, A. C., Neri, D. (2014). Effects of grapevine leafroll associated virus 3 infection on growth,leaf gas exchange, yield and basic fruit chemistry of Vitis viniferaL. cv. Cabernet Franc. Scientia Horticulturae, 170, 228-236.

Gambino, G., Cuozzo, D., Fasoli, M., Pagliarani, C., Vitali, M., Boccaccio, P., et al. (2012). Effects of Grapevine Rupestris Stem Pitting-Associated Virus on Vitis vinifera L. V: Ferguson B. (Ed.), Proceedings of the 17th Congress of the International Council for the Study of Virus and Virus-like Diseases of the Grapevine (ICVG) (9091). Davis, California, USA: Foundation Plant Services, University of California, Davis.

Jooste, A. E. C., Molenaar, N., Maree, H. J., Bester, R., Morey, L., de Koker, W. C., et al. (2015). Identification and distribution of multiple virus infections in Grapevine leafroll diseased vineyards. European Journal of Plant Pathology, 142(2), 363375. DOI: $10.1007 / \mathrm{s} 10658-015-0620-0$

Korošec-Koruza, Z. (1992). Virusne bolezni vinske trte - pomen pri pridelavi grozdja. Sodobno kmetijstvo, 25, 219-222.

León, J., Rojo, E., Sánchez-Serrano, J.J. (2001). Wound signalling in plants. Journal of Experimental Botany, 52, 1-9. DOI: 10.1093/jexbot/52.354.1

Lichtenthaler, H. K., Buschmann, C., Knapp M. (2005). How to correctly determine the different chlorophyll fluorescence parameters and the chlorophyll fluorescence decrease ratio $\mathrm{R}_{\mathrm{Fd}}$ of leaves with the PAM fluorometer. Photosynthetica 43, 379-393.

Martelli, G. P. (2014). Directory of virus and virus-like diseases of the grapevine and their agents. Journal of Plant Pathology, 96 Supl, 1-136. DOI: http://dx.doi.org/10.4454/JPP.V96I1SUP
Martelli, G. P., Arganovsky, A. A., Bar-Joseph, M., Boscia, D., Candresse, T., Coutts, R. H. A., et al. (2002). The family Closteroviridae revised. Archives of Virology, 147(10), 2039-2044. DOI: $10.1007 / \mathrm{s} 007050200048$

Martelli, G. P., Boudon-Padieu, E. (2006). Directory of infectious diseases of grapevines. International Centre for Advanced Mediterranean Agronomic Studies. Options Méditerranéennes Ser. B. Studies and Research, 55, 59-75.

Moutinho-Pereira, J., Correia, C. M., Goncalves, B., Bacelar, E. A., Coutinho, J. F., Ferreira, H. F., et al. (2012). Impacts of leafroll-associated viruses (GLRaV-1 and -3) on the physiology of the Portugese grapevine cultivar 'Touriga Nacional' growing under field conditions. Annals of Applied Biology, 160, 237-249. DOI: 10.1111/j.17447348.2012.00536.x

Osman, F., Leutenegger, C. H., Golino, D., Rowhani, A. (2007). Real-time RT-PCR (TaqMan ${ }^{\circledR}$ ) assays for the detection of Grapevine Leafroll associated viruses 1-5 and 9. Journal of Virological Methods, 141, 22-29. DOI: 10.1016/j.jviromet.2006.11.035

Pearson, R. C., Goheen, A. C. (1998). Compendium of grape diseases. 4th ed. St. Paul, The American Phytopathological Society Press.

Prosser, S. W., Goszczynski, D. E., Meng, B. (2007). Molecular analysis of double-standed RNAs reveals complex infection of grapevines with multiple viruses. Virus Research, 124, 151-159. DOI: 10.1016/j.virusres.2006.10.014

Reynard, J.-S. Gugerli, P. (2015). Effects of Grapevine red blotch-associated virus on vine physiology and fruit composition of field grown grapevine cv. Gamay. V: Ertunç F. (Ed.), 18th Congress of the International Council for the Study of Viruses and Virus-like Diseases of Grapevine (ICVG) (pp. 237235). Ankara, Turkey: ICVG.

Rowhani, A., Golino, D. A., Klaassen, V., Sim, S. T., Gouran, M., Al Rwahnih, M. (2015). Grapevine leafroll associated virus 3: Effects on rootstocks, vine, performance, yield and berries. V: Ertunç F. (Ed.), 18th Congress of the International Council for the Study of Viruses and Virus-like Diseases of Grapevine (ICVG) (pp. 161-162). Ankara, Turkey: ICVG.

Sampol, B., Bota, J., Riera, D., Medrano, H., Flexas, J. (2003). Analysis of the virus-induced inhibition of photosynthesis in malmsey grapevines. New Phytologist, 160, 403-412. DOI: 10.1046/j.14698137.2003.00882.x 
Santini, D., Rolle, L., Cascio, P., mannini, F. 2011. Modification in Chemical. Physical and Mechanical Properties og Nebbiolo (Vitis vinifera L.) Grape Berries Induced by Mixed Virus Infection. South African Journal of Enology and Viticulture, 32(2), $183-189$.

Sforza, R., Boudon-Padieu, E., Greif, C. (2003). New mealybug species vectoring Grapevine leafrollassociated viruses-1 and -3 (GLRaV-1 and -3 ). European Journal of Plant Pathology, 109, 975981. DOI: 10.1023/B:EJPP.0000003750.34458.71

Spring, J.-L., Reynard, J.-S., Gugerli, P. (2012). Influence of the Grapevine Leafroll Associated Virus (GLRaV-1) and Grapevine Fleck Virus $(\mathrm{GFkV})$ on the Grape and Wine Production of cv. Gamay. V: Ferguson B. (Ed.), Proceedings of the 17th Congress of the International Council for the Study of Virus and Virus-like Diseases of the Grapevine (ICVG) (90-91). Davis, California,
USA: Foundation Plant Services, University of California, Davis.Tomažič, I., Petrovič, N., Korošec-Koruza, Z. (2005). Effects of rugose wood and GLRaV-1 on yield of cv. 'Refošk' grapevines. Acta agriculturae Slovenica, 85(1), 91-96.

Tomažič, I., Vrhovšek, U., Korošec-Koruza, Z. (2003). The influence of virus diseases on grape polyphenols of cv.'Refošk'. Zbornik Biotehniške fakultete, Univerze v Ljubljani, Kmetijstvo, 81(2), 287-295.

Vodnik, D. (2001). Fiziologija rastlin - praktične vaje. Ljubljana: Univerza v Ljubljani Biotehniška fakulteta.

Zufferey, V., Murusuer, F., Schultz, H. R. (2000). A model analysis of tje photoynthetic response of Vitis vinifera L. cvs Riesling and Chasselas in the field: I. Interaction of age, light and temperature. Vitis, 39(1), 19-26. 